\title{
Frequency of Board Meetings and R\&D Investment Strategy: Evidence from OECD Countries
}

\author{
Aws AlHares ${ }^{*}$, Collins Ntim², Osama Al-Hares ${ }^{3}$, Ruba Al Abed ${ }^{4}$ \\ ${ }^{1}$ Department of Accountancy and Finance, Business School, University of Huddersfield, Huddersfield, UK \\ ${ }^{2}$ Department of Accounting, Southampton Business School, University of Southampton, Southampton, UK \\ ${ }^{3}$ Department of Finance and Accounting, University of Wollongong in Dubai, Dubai, UAE \\ ${ }^{4}$ School of Business Studies, College of the North Atlantic in Qatar, Doha, Qatar \\ Email: *aws.alhares@hud.ac.uk, aalhares@yahoo.co.uk
}

How to cite this paper: AlHares, A., Ntim, C., Al-Hares, O. and Al Abed, R. (2018) Frequency of Board Meetings and R\&D Investment Strategy: Evidence from OECD Countries. Theoretical Economics Letters, 8, 3016-3033.

https://doi.org/10.4236/tel.2018.814187

Received: August 21, 2018

Accepted: October 21, 2018

Published: October 24, 2018

Copyright $\odot 2018$ by authors and Scientific Research Publishing Inc. This work is licensed under the Creative Commons Attribution International License (CC BY 4.0).

http://creativecommons.org/licenses/by/4.0/

\begin{abstract}
This study seeks to examine the impact of frequency of board meetings on R\&D investment strategy in OECD countries. The study uses a panel data of 200 companies from Anglo American and European countries between 2010 and 2014. The ordinary least square regression is used to examine the relationships. Additionally, to alleviate the concern of potential endogeneity, we use fixed effect regression, two-stage least squares using instrumental variables. The results show that there is a negative and significant relationship between frequency of board meetings and R\&D investment strategy, with a greater significance among Anglo American countries than among Continental European countries. The rationale for this is that the legal and accounting systems in the Anglo American countries have greater protection through greater emphasis on compliance and disclosure and therefore allowing for less risk-taking. Future research could investigate R\&D investment strategy using different arrangement, conducting face-to-face meetings with firm's directors and shareholders. This study extends, as well as contributes to the extant CG literature by offering new evidence on the effect of frequency of board meetings on R\&D investment strategy between two different traditions. The findings will help regulators and policy makers in the OECD countries in evaluating the adequacy of the current CG reforms to prevent management misconduct and scandals.
\end{abstract}

\section{Keywords}

R\&D, Corporate Governance, Anglo-American Tradition, Continental European Tradition, OECD Countries, Frequency of Board Meetings 


\section{Introduction}

Corporate governance (CG) mechanisms are important, considering that CG is about how companies use their resources to resolve conflicts among their many stakeholders [1]. Country characteristics exert a great deal of influence on the CG systems under which companies operate. For example, countries have unique legal systems, and these systems influence the nature of the corporate rights that companies must recognise in doing business. Legal systems are important because of the significant external controls that they exert on the companies working within them. Other unique factors that play an important role in this study are the particular accounting practices used, the unique characteristics of the country and their cultures.

The key conceptual issues used in this paper are intended to show how CG mechanisms are highly determined by the specific countries in which firms operate, and how the specific mechanisms that are found to be useful in the particular countries are based on the legal, accounting and auditing practices as well as on the specific ownership and debt issues that are common in those countries. Moreover, culture also influences customs, general worldview, attitudes and values, all of which are instrumental in how firms and their managers carry out their business operations [2] [3] [4] [5] [6].

The literature on the relationship between frequency of board meetings and firm performance, particularly with respect to risk-taking, is not conclusive. According to Vafeas [7], some believe that frequent board meetings would ultimately have a positive impact on a firm's risk-taking, but another view holds that board meetings do not benefit shareholders of a firm. However, there appears to be more support for frequent board meetings benefitting forecasts of management earnings [8]. Another study shows that frequent meetings contribute to improved firm performance [9].

It is also expected that the factors that influence CG would also influence $R \& D$ in organizations [10] [11] [12] [13] [14]. Two important questions that would be addressed in this paper are: How does CG drive R\&D and how does board structure moderate the assessment of $R \& D$ ? The objective of this paper is to see how $C G$ plays a role in the decisions to promote $R \& D$ in organisations, how the different types of board would either promote or discourage R\&D and how management makes decisions regarding $\mathrm{R} \& \mathrm{D}$.

The sample firms used in this paper are drawn from firms that are listed in the World's Biggest Public Companies listing, FORBES Global 2000 Leading Companies [15]. The sample is made up of 200 firms that were taken from 10 or $29.4 \%$ of the 34 OECD countries. The 200 firms have been selected both from the Anglo American tradition, which include firms from the five countries of UK, US, Australia, Canada and Ireland, and from the Continental European tradition, which includes firms from the five countries of Germany, France, Italy, Japan and Spain. These firms are drawn from 10 industries, namely, basic materials, consumer goods, consumer services, financials, health care, industrials, oil 
and gas, technology, telecommunications, and utilities. The period that was focused on was from 2010 to 2014, resulting in 1000 firm-year observations.

The paper will begin by giving an overview of the OECD, showing how CG became an important subject and will then give a historical overview of how CG came to be introduced. It is in this context that the paper will look at how frequency of board meetings has an impact on R\&D investment strategy.

\section{Corporate Governance and R\&D: A Review}

The OECD, formed on December 14, 1960, started operations on September 30, 1961, taking up the mantle left by the Organisation for European Economic Co-operation (OEEC). When the OEEC was formed on April 16, 1948, with 18 European nations, it was in response to the Marshall Plan, a plan to rehabilitate the European economies that were badly ravaged through Europe's involvement in the war effort. This organisation was formed on the recommendation of George C. Marshall, U.S. Secretary of State, who maintained that if the American government was to move forward with helping the rehabilitation of European economies, there had to be "some agreement among the countries of Europe as to the requirements of the situation and the part those countries themselves will take" [16] [17].

Encountering many difficulties, the countries making up the OEEC saw their organisation as important but recognised that "broader co-operation will make a vital contribution to peaceful and harmonious relations among the people of the world", and that expansion of trade was necessary for "economic development of countries and the improvement of international relations". They agreed to be reconstituted under the banner of the Organisation of Economic Co-operation and Development [18] [19]. It was with this mission that the OECD was formed, consisting of the 18 members of the OEEC, as well as the United States and Canada.

The OECD provided the means whereby countries could work together on matters of common interest, and on issues that arose in their domestic economies that had the potential to influence their relations with other nations. As nations engaged in trade and investment, it was expected that they would need common understanding for smooth relations. As the OECD [16] explains, the organisation "provides a forum in which governments can work together to share experiences and seek solutions to common problems" [17].

In the 1980s and 1990s, many OECD countries were challenged by financial scandals affecting their populace [16] [18]. The OECD recognised this as an area of common concern for its member countries. Governments needed to restore confidence in their economies that were compromised by scandal. They also needed to establish healthy financial environments for sustainable development, and to foster renewed confidence among investors, both domestically and globally.

In order to deal with risk, IECD (2004) made some risk reform recommenda- 
tions. The second Principles of CG (2004) were said to focus on three main areas. According to Kirkpatrick [20] [21], the three main areas were in "ensuring the basis for an effective CG framework which was before largely implicit," "the effective exercise of ownership" and "dealing with conflicts of interest" [17] [19].

Subsequently in order to investigate how CG drives R\&D and how board structure moderates the assessment of $\mathrm{R} \& \mathrm{D}$, it would be needful to check the mechanisms of CG available in organisations to support R\&D [21] [22] [23]. Firms must pay significant concern to R\&D [24] [25].

\section{Multi Theoretical Framework}

The theories that can be used to discuss this relation between frequency of board meetings and risk-taking is agency theory, which shows the importance of looking after the interests of shareholders and promoting firm performance; resource dependence theory, since the board serves as a resource, improving firm value; and institutional theory, which is based on the idea that managers and directors will take measures that would help them to influence others. More frequent meetings may help give the impression that the firm has a board that is actively working; however, there is no relation and the null hypothesis is rejected.

\subsection{Agency Theory}

Agency theory is based on the separation of the roles of owner and manager, or of possession and control [26]. The inference here is that experts are hired as managers to manage the corporation, and are expected to look after the interests of the owners [26]. With the separation of ownership and control, the expectation is that organisations will be managed expertly, with the managers taking the place of the owners, and keeping the owners' interest as their mission [27] [28].

As Lai and Chen [29] point out, major stakeholders or shareholders have been seen as more likely to desire little risk and more growth and that stakeholder gains in the organisation tended to favour the major shareholders more with better returns than other stakeholders. As Gamble and Kelly [30] point out, shareholders are seen as privileged, since the company focuses on protecting the interests of shareholders. Having alliance partners as one of the stakeholders in an organisation leads to tough competition in the global environment. This competitiveness is seen as making the organisation more efficient, very different from firms that face competition as they develop their own know-how [29].

Garmaise and Liu point to the fact that managers of organisations, under agency theory, are prone to investment, even when there is an indication that conditions may not be ideal. Dishonest managers would expose the organisation to systemic risks by taking chances and investing when there are indications that it may not be the best decision. In these instances, dishonest or corrupt managers are generally looking out for their own self-interest. 


\subsection{Resource Dependence Theory}

Resource dependence theory holds that boards of directors are important to the functioning and performance of an organisation because the expertise and connections with others in the outside environment that individual board members have helps the organisation to secure resources [31]. The corporate board and outside directors are therefore seen as important for the organisation's performance. Board member diversity and external networks among board members and other organisations are important factors in resource dependence theory.

Resource dependence theory also shows that boards of directors with "broad and deep levels of knowledge" are in an advantageous position to make use of this knowledge in the wider external environment [32].

\subsection{Institutional Theory}

Institutional theory examines the stability and survival of the organisation, and highlights institutional norms and rules that the organisation can incorporate in order to promote its longevity.

Great risk could result when professionals accept each other's ideas without questioning them, because of peer influence. For example, Westphal and Zajac [33] highlight the risk-taking that is involved by pointing to the Parmalat scandal in which members of the financial community accepted reports, presentations and press releases because of "institutional ascription" or because these professionals who were interconnected probably through boards, simply accepted each other's words as truth (p. 638).

\section{Frequency of Board Meetings and Risk-Taking: Literature Review and Hypotheses Development}

Policy-makers and researchers express concern whether the frequency of board meetings is related to financial performance of companies. It was conjectured that more frequent board meetings lead to more monitoring of managers, which can improve financial performance [7]. It was also thought that regular meetings allow directors the opportunity to discuss strategies, and to more frequently assess how managers are performing [7]. According to Mangena and Tauringana [9], when meetings are held frequently, directors receive timely information about the organisation and have the opportunity to address developing problems more promptly. Besides keeping directors informed, frequent board meetings develop closer bonds among directors [34]. Also, conscientious directors attend meetings regularly and participate in board activities.

An opposing view suggests that shareholders do not gain much from board meetings. While the board was seen as protecting the interests of shareholders, meetings did not fulfill that goal. According to Vafeas [7], frequency of board meetings does not accomplish much, since the amount of time that board members spend together does not really involve much genuine exchange that is relevant to shareholders. This is because of the amount of routine involved in board 
meetings [7]. Vafeas explains that several management reports have to be presented, and various formalities have to be acknowledged at board meetings [7]. Lipton and Lorsch [34] also pointed out that frequent board meetings do not help shareholders, because these meetings take time away from monitoring management. It is also noted that frequent board meetings cost the company, in terms of expenses to cover travel, refreshments and other board activities [7]. This leads us to propose the following hypothesis.

H1: There is no statistically significant relationship between the frequency of board meetings and R\&D investment strategy.

\section{Research Design}

\subsection{Data Collection}

This study uses the OECD CG Principles (2004) to investigate the quality of CG practices in the companies used in the sample. CG data are obtained manually from annual reports. Annual reports are the main source of information for this study, and the assumption is made that the internal CG variables presented are reliable. The rationale for this is that the information provided by management to the shareholders must be accurate. Therefore, 200 annual reports for the companies provide the majority of data.

The annual reports were obtained from the Perfect Information Database and companies' website. When annual reports were not readily available, and when data was not available in the Perfect Information Database, the company was contacted directly through phone call or email, or through the companies' website. The R\&D expenditure data obtained from the annual reports of the companies were listed in the sample. The data were obtained for the years between 2010 and 2014 immediately after the financial crisis, and additional information obtained from databases, such as DataStream. These data would come primarily from the item "other cash payment related to operating activities" or similar identification in the notes to the financial statement in the annual reports.

The firm-level data include firm size, measured by log of total assets, sales growth, audit committee number, CG committee number and leverage, as well as year dummies and country dummies. The country-level data include stock market capitalisation, corruption index, inflation, GDP per capita, Hofstede's culture variable (masculinity and power distance) and exchange rate. These include the country's legal system, whether common law or civil law. Countries with common law systems tend to have better protection for shareholders than countries with civil law systems. The accounting system used, whether based on international or local accounting standards, is also important, as different systems have different reporting requirements and notions of acceptable practice. The CG system used, whether Anglo-American or Continental-European, also has different requirements and different protections for shareholders. A country's GDP gives an indication of the prosperity and size of the economy, and the 
level of investment in the economy. The level of corruption in the country, its inflation rate and the treatment of shareholders' rights are all factors that are significant to investors, affecting the amount of caution that an investor should exercise when investing in a particular economy. Cultural variables are important factors that shed light on an economy. This information is accessed from the World Bank website and other global sources of financial information on countries, as well as from the World Federation of Exchanges. Hofstede's cultural variables also help identify the manner in which companies in particular countries approach business dealings.

\subsection{Sample}

The sample used in the larger study consisted of 200 companies drawn from the Anglo American tradition, including companies from the five countries of Australia, Canada, Ireland, UK and US, and from the Continental European tradition, including companies from the 5 countries of France, Germany, Italy, Japan and Spain. Ten industries, basic materials, consumer goods, consumer services, financials, health care, industrials, oil and gas, technology, telecommunications, and utilities, were represented among these companies. The firms that were used in this study on R\&D were drawn from the original sample, and included only those companies that had R\&D. The period that was focused on was from 2010 to 2014, resulting in 1000 firm-year observations. There were a total of 122 companies that had $R \& D$ and 78 did not have $R \& D$. Japan had the highest number of companies, 18 , with $\mathrm{R} \& \mathrm{D}$ and the lowest, 2, without $\mathrm{R} \& \mathrm{D}$. The companies in these lists would be compared to see what aspects of CG they possess or do not possess, and factors that may influence R\&D. Also, these countries would be compared in terms of country level characteristics, to see what characteristics are most associated with R\&D investment and those that are most associated with its absence. The sample firms that were used in this paper were companies listed in the World's Biggest Public Companies listing, FORBES Global 2000 Leading Companies [15].

The reason for selecting these companies from both the Anglo-American and the Continental European traditions, from the particular industries mentioned above, and covering the period from 2010 to 2014 is that these are important factors in highlight whether the process chosen can be replicated with the same results at different periods. The time period is crucial because it covers a period after the financial crisis. The fact that companies are drawn from different traditions shows that these companies have different practices because of differences in laws, accounting and tax practices and country characteristics. The fact that different industries are used is also important because of the characteristics, importance, and performance of these industries in their respective economies.

An inclusion criterion of the companies taking part in the study was that they had experienced the global financial crisis, and data was available for a period after this event. An exclusion criterion was that any firms that had independent 
variables missing that were necessary for the analysis would be eliminated from the sample. Utility firms and firms from the financial industry were also excluded, as these industries have a different capital structure and are heavily regulated, which is likely to impact their governance structures differently than firms in other industries [35] [36] [37].

\subsection{Variables Measurement and Regression Model}

Table 1 summarises all variables used in conducting the empirical study. The measurement of Board structure is measured on the basis of the frequency of board meetings (FBM). Frequency of board meetings refers to how often the board meets.

Lang and Jagtiani [38] point out that CG and credit risk management were important elements contributing to the 2007 financial crisis. The strains that took place as a result of poor risk management and the lack of CG led to the collapse of the financial market [38].

Control variables that were thought to be able to influence risk-taking were integrated. For instance, firm size was shown as a logarithm of the total assets in each year. Country information would be obtained from global sources, such as country statistics, and company information would be obtained from company websites as well as from annual reports. A valuation model and panel data from companies in the United States, UK, Canada, Ireland, Australia, France, Spain, Germany, Japan and Italy will be used. This study set out to examine the how frequency of board meetings influence risk-taking measured by R\&D intensity and how country characteristics moderate the relationship between risk-taking and firm value.

Ordinary least squares (OLS) regression would be used to test our hypothesis. The dependent variable in these regressions is the risk-taking. Since it may be influenced by past performance, growth, ownership characteristics and CG characteristics, among others, all of these variables are included in the regression analysis to control for confounding factors [39] [40]. Year and industry dummies would be used in all regressions in order to control for the year and the industry. Based on the above hypothesis, the following model is proposed and with the aim to be tested using the ordinary least square (OLS)

$$
R T_{i t}=\alpha_{0}+\beta_{1} F B M_{i t}+\sum_{i=1}^{n} \beta_{i} F C O N T R O L S_{i t}+\sum_{i=1}^{n} \beta_{i} C C O N T R O L S_{i t}+\varepsilon_{i t}
$$

\section{Empirical Findings}

\subsection{Descriptive Analysis and Bivariate Correlations}

Table 2 reports the descriptive analysis of data relating to the independent variable. For example, the minimum number of meetings was (0) and the maximum was (35) in the overall sample period. The average over the sample period is (8.08) and the standard deviation is (3.957). Table 2 presents the control variables, which are considered to have an influence on risk-taking among 
Table 1. Variables definition and measurement.

\begin{tabular}{|c|c|}
\hline FBM & $\begin{array}{l}\text { A binary number of one if a firm's board of directors meets at least four times in } \\
\text { a financial year, and zero otherwise. }\end{array}$ \\
\hline $\mathrm{R} \& \mathrm{D} /$ Sales & Natural logarithm of the ratio of $R \& D$ expenditure to total sales \\
\hline SG & $\begin{array}{l}\text { The ratio of current year's sales minus previous year's sales, all divided by } \\
\text { previous year's sales }\end{array}$ \\
\hline FS & Natural logarithm of the book value of total assets \\
\hline $\mathrm{AC}$ & Total number of Audit Committee \\
\hline CGC & Total number of CG Committee \\
\hline LVG & The ratio of total debt to total assets \\
\hline CGY & The rise in the stock price divided by the original price of the security \\
\hline SMC & The market value of the shares outstanding \\
\hline CORR IDX & The misuse of public power for private benefit \\
\hline INF & The rate at which the general level of prices for goods and services is rising \\
\hline GDPC & Gross domestic product (GDP) divided by number of people in the country \\
\hline POP & People living in a country \\
\hline POWD & $\begin{array}{l}\text { The degree to which the less powerful members of a society accept and expect } \\
\text { that power is distributed unequally }\end{array}$ \\
\hline ANGL & A dummy variable for Anglo American countries (1), Continental countries (0) \\
\hline $\mathrm{CON}$ & A dummy variable for each country: UK (DU UK), US (DU US) \\
\hline $\mathrm{Y}$ & $\begin{array}{l}\text { A dummy variable for each year of the ten years from 2010-2014, } 2010 \text { (DU 10), } \\
2014 \text { (DU14) }\end{array}$ \\
\hline
\end{tabular}

Table 2. Summary descriptive statistics of the independent and control variables.

\begin{tabular}{cccccc}
\hline & Means & Median & Std, Dev. & Min & Max \\
\hline Frequency of Board Meetings & 8.08 & 17.5 & 3.957 & 0 & 35 \\
Firm Size & 4.2724 & 4.2116 & 0.6170 & 2.4641 & 5.8757 \\
Sales Growth & 0.0752 & 0.0434 & 0.1772 & -0.4314 & 2.3865 \\
Audit Committee No. & 4.28 & 4.00 & 1.114 & 2 & 8 \\
CG Committee No. & 3.75 & 4.00 & 1.328 & 1 & 9 \\
$\quad$ Leverage & 0.6043 & 0.6151 & 0.1762 & 0.0257 & 1.2544 \\
Stock Market Capitalisation & 6.2165 & 6.2505 & 0.5672 & 4.7808 & 7.4204 \\
Corruption Index & 1.848 & 1.869 & 0.088 & 1.59 & 1.94 \\
$\quad$ Inflation & -1.611 & -1.69 & 0.606 & -2.69 & 0.0 \\
GDP Per Capita & 4.646 & 4.66 & 0.086 & 4.462 & 4.83 \\
Power Distance & 1.63 & 1.59 & 0.113 & 1.44 & 1.83 \\
\hline
\end{tabular}

Notes: Variables are defined as follows: Frequencies of Board Meetings (FBM), Sales Growth (SG), Firm Size (FS), Audit Committee No. (AC NO), CG Committee No. (CGC NO), Stock Market Capitalisation (SMC), Corruption Index (CORR IDX), Inflation (INFL), Leverage (LVG), Anglo American (ANG), GDP per Capita (GDPC), Power Distance (POWD). 
frequency of board meetings. These variables were therefore incorporated into the figures in order to give a more accurate account of their influence on risk-taking. For example, sales growth (SG) reveals the mean of $7.52 \%$ and standard deviation of $17.72 \%$. The minimum value is $-43.14 \%$ and the maximum is $238.65 \%$. What this shows is that there is a wide difference in sales growth between companies. Firm Size (FS), which is derived as logarithm of the book value of total assets, has a mean value of 4.2724 , ranging from 2.4641 to 5.8757 . The number of audit committees (AC NO) is seen as having a range from 2 to 8 . The number of CG committees (CGC NO) is between 1 and 9.

Table 3 shows results of correlation matrices for these study variables in order to examine multicollinearities among variables. The coefficients of Pearson's and Spearman's are used as a robustness check, the direction and the magnitude of coefficients shows in correlation matrices are almost the same, indicating non-existence of non-normality problems. Additionally, the coefficient of both Pearson's and Spearman's shows that the level of correlation among variables used are relatively weak, indicating non-existence of serious multicollinearity problems. Moreover, the values of Variance Inflation Factor (VIF) reported in Table 4, less than 10, indicating that there is no serious multicollinearity problem [40]. The presence of heteroscedasticity was also tested using Breusch-Pagan test and the p-value is 0.166 , indicating that heteroscedasticity is not present in this model.

\subsection{Regression Analysis}

Table 4 represents the findings of the OLS analysis of Frequency of board meetings on risk-taking. It shows a statistically significant and negative relationship

Table 3. Pearson's and Spearman's correlation matrices of the variables.

\begin{tabular}{|c|c|c|c|c|c|c|c|c|c|c|c|}
\hline & SG & FS & AC NO & CGC NO & SMC & CORR IDX & INFL & LVG & GDPC & POWD & MAS \\
\hline SG & 1 & 0.026 & -0.016 & 0.029 & $0.081^{\star *}$ & $0.062^{*}$ & $0.119^{* * *}$ & -0.054 & 0.075 & $-0.069^{\star *}$ & $0.212^{* * *}$ \\
\hline $\mathrm{AC} \mathrm{NO}$ & $0.056^{\star}$ & $-0.111^{\star * *}$ & 1 & $0.365^{\star \star \star}$ & $0.335^{\star * *}$ & $0.328^{\star * *}$ & 0.074 & 0.074 & -0.087 & $0.209^{\star * *}$ & $-0.153^{\star * *}$ \\
\hline CGC & $0.091^{* * *}$ & $-0.105^{\star \star \star}$ & $0.308^{\star * *}$ & 1 & $0.267^{\star * *}$ & $0.447^{\star * *}$ & $0.324^{* * *}$ & $0.091^{\star *}$ & $0.187^{\star * *}$ & $0.111^{\star * *}$ & 0.063 \\
\hline SMC & $0.059^{\star *}$ & -0.098 & $0.224^{* * *}$ & $0.187^{\star * *}$ & 1 & $0.117^{\star * *}$ & $0.299^{* * *}$ & $-0.139^{\star * *}$ & $-0.097^{\star * *}$ & 0.056 & $0.357^{\star * *}$ \\
\hline $\begin{array}{c}\text { CORR } \\
\text { IDX }\end{array}$ & $0.227^{\star * *}$ & $-0.157^{\star \star *}$ & $0.264^{* * *}$ & $0.498^{\star * *}$ & $0.081^{* * *}$ & 1 & $0.297^{\star * *}$ & 0.074 & $0.616^{\star * *}$ & -0.154 & $0.099^{* * *}$ \\
\hline INFL & $0.194^{* * *}$ & $0.194^{\star * *}$ & $-0.069^{\star}$ & $0.322^{\star * *}$ & $0.421^{\star * *}$ & $0.253^{\star * *}$ & 1 & $0.149^{* * *}$ & $-0.246^{\star * *}$ & $-0.174^{\star * *}$ & $0.499^{* * *}$ \\
\hline LVG & -0.086 & $-0.109^{\star * *}$ & $0.234^{\star * *}$ & $0.189^{* * *}$ & $-0.092^{\star * *}$ & $0.541^{* * *}$ & $-0.309^{\star * *}$ & 1 & $-0.221^{\star \star \star}$ & $0.159^{* * *}$ & $-0.421^{\star * *}$ \\
\hline POWD & $0.223^{* * *}$ & $0.085^{\star}$ & $-0.063^{\star *}$ & $0.118^{\star * *}$ & $0.327^{\star * *}$ & $0.159^{\star * *}$ & $0.673^{* * *}$ & -0.097 & $-0.491^{\star * \star}$ & 1 & $0.724^{\star * *}$ \\
\hline MAS & $-0.123^{\star \star *}$ & $-0.089^{\star \star \star}$ & $0.189^{* * *}$ & -0.745 & $-0.345^{\star \star *}$ & $0.183^{\star * *}$ & $-0.529^{\star * *}$ & 0.325 & $0.506^{\star * *}$ & $0.068^{* *}$ & 1 \\
\hline
\end{tabular}

Notes: the upper right half of the table shows Pearson's parametric correlation coefficients, whereas the bottom left half of the table contains Spearman's non-parametric correlation coefficients. ${ }^{* *}$, and ${ }^{*}$ denote correlation is significant at the $1 \%$, and $5 \%$ level, respectively (two-tailed tests). Variables are defined as follows: Sales Growth (SG), Firm Size (FS), Audit Committee No. (AC NO), CG Committee No. (CGC NO), Stock Market Capitalisation (SMC), Corruption Index (CORR IDX), Inflation (INFL), Leverage (LVG), GDP per Capita (GDPC), Power Distance (POWD) and Masculinity (MAS). 
Table 4. OLS regression results of frequency of board meetings on R\&D intensity.

\begin{tabular}{|c|c|c|c|c|c|c|c|}
\hline & All firm years & 2010 & 2011 & 2012 & 2013 & 2014 & VIF \\
\hline Adjusted $\mathrm{R}^{2}$ & 0.191 & 0.127 & 0.121 & 0.111 & 0.196 & 0.233 & - \\
\hline Standard Error & 0.718 & 0.681 & 0.738 & 0.775 & 0.752 & 0.716 & - \\
\hline Durbin-Watson & $0.555^{* * *}$ & 2.143 & 1.953 & 2.072 & 2.207 & 1.842 & - \\
\hline F-Value & 0.582 & $1.679^{\star}$ & $1.657^{\star}$ & $1.634^{*}$ & $2.253^{* * *}$ & $2.396^{\star * *}$ & - \\
\hline No. of Observations & 504 & 97 & 99 & 105 & 107 & 96 & - \\
\hline Constant & $-3.430^{\star * *}$ & $-2.412^{\star *}$ & $-1.829^{\star}$ & -1.132 & 0.148 & $-1.708^{*}$ & - \\
\hline Frequency of Board Meetings & $-4.293^{* * *}$ & -0.375 & $-2.771^{\star * *}$ & $-1.714^{*}$ & $-1.735^{\star}$ & $-2.667^{\star * *}$ & 3.046 \\
\hline Firm Size & $-2.082^{\star *}$ & -1.186 & -0.941 & -0.687 & -0.314 & -0.666 & 2.475 \\
\hline Sales Growth & 0.373 & -0.156 & -0.119 & 0.530 & -0.874 & 0.561 & 1.082 \\
\hline Audit Committee No. & $-1.625^{\star}$ & -0.015 & -1.335 & -1.172 & $-2.292^{\star *}$ & -0.051 & 1.356 \\
\hline CG Committee No. & $5.124^{* * *}$ & $2.244^{* *}$ & $1.855^{\star}$ & $1.957^{\star}$ & $2.793^{\star * *}$ & $3.012^{\star * *}$ & 1.208 \\
\hline Leverage & 0.574 & 0.297 & 1.524 & -0.055 & -0.369 & 0.390 & 1.302 \\
\hline Stock Market Capitalisation & -0.862 & 0.512 & -0.147 & -0.036 & $1.685^{*}$ & $-1999^{* *}$ & 2.704 \\
\hline Corruption Index & $2.004^{\star *}$ & -1.307 & 0.287 & 1.262 & -.251 & $2.996^{\star * *}$ & 1.1886 \\
\hline Inflation & -0.794 & $1.875^{*}$ & -1.091 & -0.877 & $-3.216^{* * *}$ & -0.207 & 1.143 \\
\hline GDP Per Capita & 0.754 & $2.974^{\star \star \star}$ & 0.326 & -1.233 & -0.268 & 0.317 & 1.211 \\
\hline Power Distance & $3.491^{* * *}$ & -1.423 & 0.989 & 1.394 & -0.314 & $2.006^{* *}$ & 1.450 \\
\hline Masculinity & 1.148 & -1.342 & 0.631 & 1.225 & -1.154 & $1.666^{*}$ & 5.011 \\
\hline Anglo American & $4.572^{* * *}$ & $-2.244^{* \star}$ & -0.251 & 0.183 & $-1.712^{\star}$ & -1.267 & 5.143 \\
\hline 2010 & 1.218 & - & - & - & - & - & 0.211 \\
\hline 2011 & 0.565 & - & - & - & - & - & 0.406 \\
\hline 2012 & 0.415 & - & - & - & - & - & 0.541 \\
\hline 2014 & -0.514 & - & - & - & - & - & 0.014 \\
\hline
\end{tabular}

Notes: coefficients are in front of parenthesis. ${ }^{* *},{ }^{* *}$ and ${ }^{*}$ denote p-value is significant at the $1 \%, 5 \%$ and $10 \%$ level, respectively. Also, year 2013 are excluded from the regression analyses. It is used as base year, respectively, for purposes of comparison.

between frequency of board meetings and risk-taking measured by $R \& D / S a l e s$, thereby providing empirical support for H1. This negative relationship suggests that the more board meetings are held, the lower the risk-taking. This relationship is based on the idea that frequent board meetings mean greater monitoring of management. The overall average for all firm years is $\left(-4.293^{* * *}\right)$ for frequency of board meetings.

This finding shows that there is a negative relationship between frequency of board meetings and risk-taking, significant to $1 \%$. This suggests that when meetings are more frequent, risk-taking will decrease. According to agency theory, board members protect shareholders' interests through their surveillance of management [7] [9]. This finding supports studies including Karamanou and Vafeas [8], who show that among 275 U.S. listed companies, frequent board meetings had a positive effect. 
However, another view is that more frequent boards meetings result in higher costs for boards and firms, eventually leading to poor performance. The theories that can be used to discuss this relation between frequency of board meetings and risk-taking is agency theory, which shows the importance of looking after the interests of shareholders and promoting firm performance; resource dependence theory, since the board serves as a resource, improving firm value; and institutional theory, which is based on the idea that managers and directors will take measures that would help them to influence others. More frequent meetings may help give the impression that the firm has a board that is actively working.

Firm size is also significant, but at $5 \%$ and negative. Firm size mattered, as firms of different sizes had different CG structures. Differences in firm size affected risk-taking. In terms of audit committees, here was also a negative relationship, significant at $10 \%$. This meant that an increase in audit committee led to a reduction in risk-taking. Significance to CG committee number was $\left(5.124^{* *}\right)$ significant at $1 \%$. This suggests that when CG increases, so does the likelihood of investment in R\&D [41] [42].

Audit committees would lead to an increase in the creditworthiness of the company, as these committees carry out more surveillance of firms, leading to better protection of shareholders' interests [30] [35]. With the country variables, corruption index, power distance and Anglo-American have relations with risk-taking that are significant at $1 \%$. Corruption index, power distance and Anglo-American have a positive relationship. The findings are $\left(2.004^{* *}\right)$ for corruption index, $\left(3.491^{\star * \star}\right)$ for power distance and $\left(4.572^{* * *}\right)$ for Anglo-American. An increase in corruption index and power distance led to increase in risk-taking. The positive significance for Anglo-American means that firms from Anglo countries perform better in terms of risk-taking than firms from Continental countries. This reflect the fact that Anglo-American system leads to a decline in risk and ultimately in credit risk. According to research, since the Anglo-American tradition has rigid CG mechanisms established by country practices, heavy emphasis is placed on compliance and disclosure, leading to reduced risk-taking.

\section{Further Analysis}

To conform the robustness of the obtained findings, additional analyses have been carried out. To test for existence of any possible endogeneity [43], this study uses fixed effect regression model to address possible firm-level heterogeneity. Therefore, the model to be assessed is identified as:

$$
R T_{i t}=\alpha_{0}+\beta_{1} F B M_{i t}+\sum_{i=1}^{n} \beta_{i} F C O N T R O L S_{i t}+\sum_{i=1}^{n} \beta_{i} C_{C O N T R O L S}+\delta_{i t}+\varepsilon_{i t}
$$

The results for model 1 are reported in Table 5 and the results are mostly similar to those in Table 4 . The findings are robust to endogeneity problems that may arise from omitted factors.

The two-stage least squares test is used with the OLS regression in order to correlate the errors that may occur in the dependent variables with the 
Table 5. OLS regression results of fixed effect of frequency of board meetings on R\&D intensity (dependent variable).

\begin{tabular}{|c|c|c|c|}
\hline & Fixed Effect & 2-Stage Least Squares & Lagged-Effect \\
\hline Adjusted $\mathrm{R}^{2}$ & 0.967 & 0.162 & 0.150 \\
\hline Standard Error & 0.134 & 0.724 & 0.770 \\
\hline Durbin-Watson & 1.776 & 0.595 & 0.694 \\
\hline F-Value & $114.574(0.000)^{* * *}$ & $4.902(0.000)^{\star * *}$ & $4.127(0.000)^{\star * *}$ \\
\hline No. of Observations & 504 & 504 & 425 \\
\hline Constant & $-2.138(0.029)^{\star *}$ & $-3.859(0.000)^{* * *}$ & $-0.293(125)$ \\
\hline Frequency of Board Meetings & $-0.155(0.587)$ & $-2.512(0.032)^{\star \star}$ & $-2.346(0.001)$ \\
\hline Firm Size & $2.273(0.024)^{\star *}$ & $2.711(0.006)^{* * *}$ & $1.281(0.452)$ \\
\hline Sales Growth & $2.703(0.008)^{\star * *}$ & $2.012(0.041)^{* *}$ & $0.464(0.218)$ \\
\hline Audit Committee No. & $-1.288(0.184)$ & $-0.875(0.387)$ & $-2.55(0.025)^{\star *}$ \\
\hline CG Committee No. & $0.662(0.506)$ & $2.752(0.005)^{* * *}$ & $0.954(0.516)$ \\
\hline Leverage & $-2.732(0.008)^{\star * *}$ & $-1.433(0.157)$ & $-1.623(0.615)$ \\
\hline Stock Market Capitalisation & $-1.221(0.211)$ & $-0.274(0.787)$ & $1.443(0.124)$ \\
\hline Corruption Index & $0.062(0.932)$ & $1.413(0.166)$ & $-0.577(0.772)$ \\
\hline Inflation & $-0.135(0.772)$ & $-1.828(0.078)^{\star}$ & $-3.860(0.002)^{\star * \star}$ \\
\hline GDP Per Capita & $0.332(0.721)$ & $0.171(0.867)$ & $-0.561(0.125)$ \\
\hline Power Distance & - & $1.216(0.110)$ & $-1.396(0.282)$ \\
\hline Masculinity & - & $2.223(0.025)^{\star \star}$ & $0.419(0.862)$ \\
\hline Anglo American & - & $0.814(0.311)$ & $-1.828(0.074)$ \\
\hline 2010 & $-2.711(0.005)^{\star * \star}$ & $-1.205(0.213)$ & $0.519(147)$ \\
\hline 2011 & $-1.862(0.050)^{\star *}$ & $-1.272(0.188)$ & $-2.457(0.036)^{\star *}$ \\
\hline 2012 & $-0.853(0.336)$ & $-0.913(0.243)$ & $1.624(0.874)$ \\
\hline 2014 & $-1.536(0.125)$ & $-0.802(0.302)$ & - \\
\hline
\end{tabular}

independent variable and to fitting panel data model. The results stay almost the same as the results provided previously in Table 4, suggesting that our results are fairly robust to possible endogeneity issues.

\section{Conclusions}

Although several of previous studies examined the association among frequency of board meetings on performance [44] [45] [46] [47] [48], studies examining how and why board mechanisms impact risk-taking are rare. Therefore, this paper investigates the relationship between frequency of board meetings and risk-taking that is measured by R\&D intensity [49]-[54], as the natural logarithm of the ratio of $\mathrm{R} \& \mathrm{D}$ expenditure to sales ( $\mathrm{R} \& \mathrm{D} / \mathrm{Sales})$. The findings indicate that there is a strong negative relationship between frequency of board meetings and risk-taking as measured by the intensity of $\mathrm{R} \& \mathrm{D}$ in the companies [55] [56] [57] 
[58] [59].

In addition, a comparison of the Anglo American countries and the European countries reveals that both sets of countries show a negative relationship between frequency of board meetings and risk-taking, but that this relationship is shown to be much smaller in the Continental European countries than in the Anglo American countries. The rationale for this seems to be that in the Anglo American countries, the legal and accounting systems in the Anglo American system have greater protection through greater CG and heavy emphasis is placed on compliance and disclosure and therefore allowing for less risk-taking.

Frequency of board meetings is significant and negative. This supports the position that the more often board meetings are held, the less risk there is. The literature shows that frequent meetings can lead to a reduction in risk [60]-[68]. This may be because more frequent board meetings mean more monitoring of management, thereby reducing risk-taking [7]. This is based on the idea that there is more strategising at board meetings [69], thereby promoting more creative solutions to problems [7]. Frequent board meetings were also thought to be effective in promoting closer ties between members [43]. But Vafeas [7] suggests that the argument can be made that more frequent board meetings do not help, because more costs are associated with holding these meetings.

\section{Conflicts of Interest}

The authors declare no conflicts of interest regarding the publication of this paper.

\section{References}

[1] Daily, C.M., Dalton, D.R. and Cannella, A.A. (2003) Corporate Governance: Decades of Dialogue and Data. Academy of Management Review, 28, 371-382. https://doi.org/10.5465/amr.2003.10196703

[2] AlHares, A. and Ntim, C.G. (2017) A Cross-Country Study of the Effects of Institutional Ownership on Credit Ratings. International Journal of Business and Management, 12, 80-99. https://doi.org/10.5539/ijbm.v12n8p80

[3] AlHares, A.M. (2017) A Cross-Country Study of the Effects of Corporate Governance Mechanisms on Risk-Taking, Credit Rating and Cost of Capital. Doctoral Dissertation, University of Huddersfield, Huddersfield.

[4] Ntim, C.G., Opong, K.K., Danbolt, J. and Thomas, D.A. (2012) Voluntary Corporate Governance Disclosures by Post-Apartheid South African Corporations. Journal of Applied Accounting Research, 13, 122-144. https://doi.org/10.1108/09675421211254830

[5] Ntim, C.G. and Soobaroyen, T. (2013) Corporate Governance and Performance in Socially Responsible Corporations: New Empirical Insights from a Neo-Institutional Framework. Corporate Governance: An International Review, 21, 468-494. https://doi.org/10.1111/corg.12026

[6] Ntim, C.G., Lindop, S. and Thomas, D.A. (2013) Corporate Governance and Risk Reporting in South Africa: A Study of Corporate Risk Disclosures in the Pre-and Post-2007/2008 Global Financial Crisis Periods. International Review of Financial Analysis, 30, 363-383. https://doi.org/10.1016/j.irfa.2013.07.001 
[7] Vafeas, N. (1999) Board Meeting Frequency and Firm Performance. Journal of Financial Economics, 53, 113-142. https://doi.org/10.1016/S0304-405X(99)00018-5

[8] Karamanou, I. and Vafeas, N. (2005) The Association between Corporate Boards, Audit Committees, and Management Earnings Forecasts: An Empirical Analysis. Journal of Accounting Research, 43, 453-486. https://doi.org/10.1111/j.1475-679X.2005.00177.x

[9] Tauringana, V. and Mangena, M. (2006) Complementary Narrative Commentaries of Statutory Accounts in Annual Reports of UK Listed Companies. Journal of Applied Accounting Research, 8, 71-109. https://doi.org/10.1108/96754260680001050

[10] Chen, L.Y., Chen, Y.F. and Yang, S.Y. (2017) Managerial Incentives and R\&D Investments: The Moderating Effect of the Directors' and Officers' Liability Insurance. The North American Journal of Economics and Finance, 39, 210-222. https://doi.org/10.1016/j.najef.2016.10.007

[11] Guldiken, O. and Daendeli, I.S. (2017) Too Much of a Good Thing: Board Monitoring and R\&D Investments. Journal of Business Research, 69, 2931-2938. https://doi.org/10.1016/j.jbusres.2015.12.062

[12] Honoré, F., Munari, F. and de La Potterie, B.V.P. (2015) Corporate Governance Practices and Companies' R\&D Intensity: Evidence from European Countries. Research policy, 44, 533-543. https://doi.org/10.1016/j.respol.2014.10.016

[13] James, B.E. and McGuire, J.B. (2016) Transactional-Institutional Fit: Corporate Governance of R\&D Investment in Different Institutional Contexts. Journal of Business Research, 69, 3478-3486. https://doi.org/10.1016/j.jbusres.2016.01.038

[14] Liao, T.L. and Lin, W.C. (2017) Corporate Governance, Product Market Competition, and the Wealth Effect of R\&D Spending Changes. Financial Management, 46, 717-742. https://doi.org/10.1111/fima.12161

[15] Forbes (2000) FORBES Global 2000 Leading Companies. https://www.forbes.com/global2000./\#5d4e83f64aa2

[16] OECD. http://www.oecd.org/finance/financial-markets/42229620.pdf

[17] OECD (2014) Risk Management and Corporate Governance. Corporate Governance, OECD Publishing. http://www.oecd.org/daf/ca/risk-management-corporate-governance.pdf

[18] OECD (2004) Principles of Corporate Governance.

[19] http://www.oecd.org/corporate/ca/corporategovernanceprinciples/31557724.pdf

[20] Kirkpatrick, G. (2009) The Corporate Governance Financial Crisis. Financial Market Trends, 61-87. https://doi.org/10.1787/fmt-v2009-art3-en

[21] Kirkpatrick, G. (2004) Improving Corporate Governance Standards: The Work of the OECD and the Principles: Organisation for Economic Cooperation and Development.

http://www.oecd.org/corporate/ca/corporategovernanceprinciples/33655111.pdf

[22] AlHares, A., Ntim, C. and King, D. (2018) Block Ownership and Companies’ R\&D Intensity: The Moderating Effect of Culture. Corporate Ownership \& Control, 15, 19-32. https://doi.org/10.22495/cocv15i2art2

[23] Munari, F., Oriani, R. and Sobrero, M. (2010) The Effects of Owner Identity and External Governance Systems on R\&D Investments: A Study of Western European Firms. Research Policy, 39, 1093-1104. https://doi.org/10.1016/j.respol.2010.05.004

[24] Pindado, J., Queiroz, V. and Torre, C. (2015) How Do Country Level Governance Characteristics Impact the Relationship between R\&D and Firm Value? R\&D Management, 45, 515-526. https://doi.org/10.1111/radm.12115 
[25] Rapp, M.S. and Udoieva, I.A. (2017) Corporate Governance and Its Impact on R\&D Investment in Emerging Markets. Emerging Markets Finance and Trade, 53, 2159-2178. https://doi.org/10.1080/1540496X.2016.1248940

[26] Tsao, S.M., Lin, C.H. and Chen, V.Y. (2015) Family Ownership as a Moderator between R\&D Investments and CEO Compensation. Journal of Business Research, 68, 599-606. https://doi.org/10.1016/j.jbusres.2014.09.001

[27] Kiel, G.C. and Nicholson, G.J. (2003) Board Composition and Corporate Performance: How the Australian Experience Informs Contrasting Theories of Corporate Governance. Corporate Governance: An International Review, 11, 189-205. https://doi.org/10.1111/1467-8683.00318

[28] Zattoni, A., Douglas, T. and Judge, W. (2013) Developing Corporate Governance Theory through Qualitative Research. Corporate Governance: An International Review, 21, 119-122. https://doi.org/10.1111/corg.12016

[29] Yoo, T. and Sung, T. (2015) How Outside Directors Facilitate Corporate R\&D Investment? Evidence from Large Korean Firms. Journal of Business Research, 68, 1251-1260. https://doi.org/10.1016/j.jbusres.2014.11.005

[30] Lai, J.H. and Chen, L.Y. (2014) The Valuation Effect of Corporate Governance on Stakeholder Wealth: Evidence from Strategic Alliances. International Review of Economics \& Finance, 32, 117-131. https://doi.org/10.1016/j.iref.2014.01.010

[31] Gamble, A. and Kelly, G. (2001) Shareholder Value and the Stakeholder Debate in the UK. Corporate Governance: An International Perspective, 9, 110-117. https://doi.org/10.1111/1467-8683.00235

[32] Abdullah, H. and Valentine, B. (2009) Fundamental and Ethics Theories of Corporate Governance. Middle Eastern Finance and Economics, 4, 88-96.

[33] Westphal, J.D. and Zajac, E.J. (2014) A Behavioral Theory of Corporate Governance: Explicating the Mechanisms of Socially Situated and Socially Constituted agency. The Academy of Management Annals, 7, 607-661. https://doi.org/10.5465/19416520.2013.783669

[34] Lipton, M. and Lorsch, J.W. (1992) A Modest Proposal for Improved Corporate Governance. The Business Lawyer, 48, 59-77.

[35] Judge, W.Q., Witt, M.A., Zattoni, A., et al. (2014) Corporate Governance and IPO underpricing in a Cross-National Sample: A Multilevel Knowledge-Based View. Strategic Management Journal, 36, 1174-1185. https://doi.org/10.1002/smj.2275

[36] AlHares, A., Ntim, C., King, D. and Byrne, R. (2018) Does Ownership Structure Improve Credit Ratings? Journal of Governance and Regulation, 7, 22-33.

https://doi.org/10.22495/jgr_v7_i2_p3

[37] Yermack, D. (1996) Higher Market Valuation of Companies with a Small Board of Directors. Journal of Financial Economics, 40, 185-211. https://doi.org/10.1016/0304-405X(95)00844-5

[38] Cheng, S. (2008) Board Size and the Variability of Corporate Performance. Journal of Financial Economics, 87, 157-176. https://doi.org/10.1016/j.jfineco.2006.10.006

[39] Lang, W.W. and Jagtiani, J.A. (2010) The Mortgage and Financial Crises: The Role of Credit Risk Management and Corporate Governance. Atlantic Economic Journal, 38, 295-316.

[40] Choi, Y.R., Zahra, S.A., Yoshikawa, T. and Han, B.H. (2015) Family Ownership and $\mathrm{R} \& \mathrm{D}$ Investment: The Role of Growth Opportunities and Business Group Membership. Journal of Business Research, 68, 1053-1061.

https://doi.org/10.1016/j.jbusres.2014.10.007 
[41] Han, J., Bose, I., Hu, N., Qi, B. and Tian, G. (2015) Does Director Interlock Impact Corporate R\&D Investment? Decision Support Systems, 71, 28-36. https://doi.org/10.1016/j.dss.2015.01.001

[42] Boone, A.L., Casares Field, L., Karpoff, J.M. and Raheja, C.G. (2009) The Determinants of Corporate Board Size and Composition: An Empirical Analysis. Journal of Financial Economics, 85, 66-101. https://doi.org/10.1016/j.jfineco.2006.05.004

[43] Black, B.S., Kim, W., Jang, H. and Park, K.S. (2015) How Corporate Governance Affect Firm Value? Evidence on a Self-Dealing Channel from a Natural Experiment in Korea. Journal of Banking \& Finance, 51, 131-150. https://doi.org/10.1016/j.jbankfin.2014.08.020

[44] Wintoki, M.B., Linck, J.S. and Netter, J.M. (2012) Endogeneity and the Dynamics of internal Corporate Governance. Journal of Financial Economics, 105, 581-606. https://doi.org/10.1016/j.jfineco.2012.03.005

[45] Adams, R.B. (2005) What Do Boards Do? Evidence from Board Committee and Director Compensation Data. Evidence from Board Committee and Director Compensation Data. EFA.

[46] Allegrini, M. and Greco, G. (2013) Corporate Boards, audit Committees and Voluntary Disclosure: Evidence from Italian Listed Companies. Journal of Management \& Governance, 17, 187-216. https://doi.org/10.1007/s10997-011-9168-3

[47] Anderson, R.C., Mansi, S.A. and Reeb, D.M. (2004) Board Characteristics, Accounting Report Integrity, and the Cost of Debt. Journal of Accounting and Economics, 37, 315-342. https://doi.org/10.1016/j.jacceco.2004.01.004

[48] Baranchuk, N. and Dybvig, P.H. (2009) Consensus in Diverse Corporate Boards. Review of Financial Studies, 22, 715-747.

[49] Conheady, B., McIlkenny, P., Opong, K.K. and Pignatel, I. (2015) Board Effectiveness and Firm Performance of Canadian Listed Firms. The British Accounting Review, 47, 290-303. https://doi.org/10.1016/j.bar.2014.02.002

[50] Donnelly, R. and Mulcahy, M. (2008) Board Structure, Ownership, and Voluntary Disclosure in Ireland. Corporate Governance: An International Review, 16, 416-429. https://doi.org/10.1111/j.1467-8683.2008.00692.x

[51] Eisenberg, T., Sundgren, S. and Wells, M.T. (1998) Larger Board Size and Decreasing Firm Value in Small Firms. Journal of Financial Economics, 48, 35-54. https://doi.org/10.1016/S0304-405X(98)00003-8

[52] Guest, P.M. (2009) The Impact of Board Size on Firm Performance: Evidence from the UK. The European Journal of Finance, 15, 385-404. https://doi.org/10.1080/13518470802466121

[53] Harjoto, M.A., Laksmana, I. and Yang, Y.W. (2014) Board Diversity and Corporate Risk Taking.

[54] Kumar, P. and Zattoni, A. (2013) Corporate Governance, Board of Directors, and Firm Performance. Corporate Governance: An International Review, 21, 311-313. https://doi.org/10.1111/corg.12032

[55] McNulty, T., Florackis, C. and Ormrod, P. (2013) Boards of Directors and Financial Risk during the Credit Crisis. Corporate Governance: An International Review, 21, 58-78. https://doi.org/10.1111/corg.12007

[56] Nakano, M. and Nguyen, P. (2012) Board Size and Corporate Risk Taking: Further Evidence from Japan. Corporate Governance: An International Review, 20, 369-387. https://doi.org/10.1111/j.1467-8683.2012.00924.x

[57] Upadhyay, A. and Sriram, R. (2011) Board Size, Corporate Information Environ- 
ment and Cost of Capital. Journal of Business Finance \& Accounting, 38, 1238-1261. https://doi.org/10.1111/j.1468-5957.2011.02260.x

[58] Wang, C.J. (2012) Board Size and Firm Risk-Taking. Review of Quantitative Finance and Accounting, 38, 519-542. https://doi.org/10.1007/s11156-011-0241-4

[59] Yawson, A. (2006) Evaluating the Characteristics of Corporate Boards Associated with Layoff Decisions. Corporate Governance: An International Review, 14, 75-84. https://doi.org/10.1111/j.1467-8683.2006.00488.x

[60] Belloc, F. (2012) Corporate Governance and Innovation: A Survey. Journal of Economic Surveys, 26, 835-864. https://doi.org/10.1111/j.1467-6419.2011.00681.x

[61] Bianchini, S., Krafft, J., Quatraro, F. and Ravix, J. (2015) Corporate Governance, Innovation and Firm Age: Insights and New Evidence. No. 201502, University of Turin, Turin.

[62] Decker, C. and Günther, C. (2017) The Impact of Family Ownership on Innovation: Evidence from the German Machine Tool Industry. Small Business Economics, 48, 199-212. https://doi.org/10.1007/s11187-016-9775-0

[63] Driver, C. and Guedes, M.J.C. (2012) Research and Development, Cash Flow, Agency and Governance: UK Large Companies. Research Policy, 41, 1565-1577. https://doi.org/10.1016/j.respol.2012.04.003

[64] Lacetera, N. (2001) Corporate Governance and the Governance of Innovation: The Case of Pharmaceutical Industry. Journal of management and Governance, 5, 29-59. https://doi.org/10.1023/A:1017907119114

[65] O'Connor, M. and Rafferty, M. (2012) Corporate Governance and Innovation. Journal of Financial and Quantitative Analysis, 47, 397-413. https://doi.org/10.1017/S002210901200004X

[66] Sapra, H., Subramanian, A. and Subramanian, K.V. (2014) Corporate Governance and Innovation: Theory and Evidence. Journal of Financial and Quantitative Analysis, 49, 957-1003. https://doi.org/10.1017/S002210901400060X

[67] Urbinati, A., Franzò, S., De Massis, A. and Frattini, F. (2017) Innovation in Family firms: A Review of Prior Studies and a Framework for Future Research. In: Brem, A. and Viardot, E., Eds., Revolution of Innovation Management, Palgrave Macmillan, London, UK, 213-246. https://doi.org/10.1057/978-1-349-95123-9_8

[68] Alnabsha, A., Abdou, H.A., Ntim, C.G. and Elamer, A.A. (2018) Corporate Boards, Ownership Structures and Corporate Disclosures: Evidence from a Developing Country. Journal of Applied Accounting Research, 19, 20-41. https://doi.org/10.1108/JAAR-01-2016-0001

[69] Sarhan, A. and Ntim, C.G. (2018) Corporate Boards, Shareholding Structures and Voluntary Disclosure in Emerging MENA Economies. Journal of Accounting in Emerging Economies, Forthcoming. 